\title{
17
}

\section{Using Baffle Boxes for Stormwater Treatment}

Gordon England and John Royal

Over the last eight years, the Brevard County Surface Water Improvement Program in Florida has used baffle boxes for stormwater sedimentation control at over 34 locations. As part of a Florida Department of Environmental Protection Demonstration Project for Indialantic Area Baffle Boxes, two baffle boxes were constructed in series on a 9.75 ha (24.1 ac) drainage basin in Sunset Park, near Indialantic. The first baffle box was installed in 1992 and long-term cleanout records have been documented on the performance of this baffle box. A second baffle box was installed in 1998 immediately upstream of the first baffle box to create a series configuration. Autosampler monitoring results for TSS, Total Phosphorus, COD, and BOD removal efficiencies are presented in this chapter for the second baffle box. In addition, the effectiveness of two baffle boxes in series is examined.

\subsection{Introduction}

The adverse impacts of sedimentation upon receiving water bodies have been well documented in recent years. In an effort to reduce sediment loadings from stormwater runoff, Brevard County's Stormwater Utility has had an active program of installing baffle boxes at stormwater pipe outfalls for sediment control. A baffle box is an inline concrete or fiberglass box with two to three chambers for sedimention. It is designed to remove sediment, pollutants

England, G.B. and J.C. Royal. 2003. "Using Baffle Boxes for Stormwater Treatment." Journal of Water Management Modeling R215-17. doi: 10.14796/JWMM.R215-17.

(C) CHI 2003 www.chijournal.org ISSN: 2292-6062 (Formerly in Practical Modeling of Urban Water Systems. ISBN: 0-9683681-7-4) 
attached to sediment, and floating trash and debris. Weirs at pipe invert levels are used to partition the box allowing for $0.91 \mathrm{~m}(3 \mathrm{ft})$ deep chambers for sediment and debris storage. Screens hang from the ceiling to collect floating trash. These screens swivel up during high flows to minimize flow blockage and upstream flooding. An important advantage of using a baffle box is that no new land is required for construction. This best management practice (BMP) can be constructed in existing drainage easements or in street right-of-ways. Baffle boxes are cleaned out with vacuum trucks and their spoil is taken to a landfill. Cleanout records have been maintained in a database for analysis of baffle box effectiveness. Long term analysis of cleanout data from over 35 baffle box installations has shown that at most locations in Brevard County, boxes should be cleaned out once or twice a year. This is dependent upon the pollutant loading characteristics in each drainage basin. In some basins with highly eroded streams or leaking pipe joints, baffle boxes have collected as much as 50,000 pounds $(2300 \mathrm{~kg})$ a month.

In 1991 a Stormwater Masterplan was completed by Brevard County for a section of the barrier island north of the Town of Indialantic. This masterplan addressed water quality and quantity problems for this watershed. This area had few stormwater treatment facilities and discharged into the Indian River Lagoon, an Estuary of National Significance. In accordance with the masterplan recommendations, a baffle box was installed along Riverside Drive at Sunset Park in 1992, in Indialantic Basin H. This demonstration project was costshared between the St. Johns River Water Management District and the National Estuary Program.

Basin $H$ is a 9.75 ha $(24.1 \mathrm{ac})$ drainage basin with medium density residential land use. Soils in this basin are predominantly Galveston-Urban Land Complex, which is a well drained sandy soil containing shell fragments. There is significant sediment loading to the streets in this basin from airborne beach sand deposition. The topography is flat with a mixture of curbed and noncurbed streets. No swales are present in the drainage area. Many of the upstream pipes leading to the baffle box are perforated corrugated metal pipes installed to lower the ground water. These pipes are not wrapped and allow considerable soil infiltration into the pipes. This causes constant base flows in the pipes with a heavy sediment load of large grain sand rolling along the bottom of the pipe during small storms.

Pollution from bed loads is not normally detected under typical storm event monitoring techniques. During large storm flows this material is suspended and is included in measurements of total suspended solids. During interevent periods this material drops to the bottom of the pipe and is stored until the next 
high flow event. The significance of these bed loads is their confounding impact on mass balance relationships and buildup/wash-off models. These loads are essentially "invisible" and represent a significant pollution source to receiving waters. In the ensuing years approximately $13,279 \mathrm{~kg}(29,275 \mathrm{lbs})$ of sediment has been removed from this box, with a peak monthly loading of $816 \mathrm{~kg}(1,800$ $\mathrm{lbs}$ ) of sediment. Sediment removal was accomplished with a vacuum truck..

Using an EPA 319(h) grant, ten baffle boxes were installed in the Indialantic watershed in 1997 and 1998. The Sunset Park location was chosen for a baffle box in series where a new unit installed $4.6 \mathrm{~m}$ (15 ft) upstream of the original baffle box. This location was chosen because it had a proven sedimentation problem and long term cleanout records. This study was designed to assess the effectiveness of a single baffle box, as well as two baffle boxes in series. It was performed at a grant compliance level, rather than to higher level academic standards.

\subsection{Methods}

Baffle Box 1, the first baffle box ever installed, had three chambers and was installed at a $90^{\circ}$ bend of an existing 24 inch $(610 \mathrm{~mm}) \mathrm{CMP}$, replacing an existing manhole. The $610 \mathrm{~mm}$ pipe entered the first chamber of the box perpendicular to the length of the box, forcing the influent water to turn $90^{0}$ before flowing in to the second chamber. The dimensions of the box were $3.38 \mathrm{~m}(11 \mathrm{ft})$ long, $1.84 \mathrm{~m}(6 \mathrm{ft})$, wide and $1.84 \mathrm{~m}(6 \mathrm{ft})$ high.

Baffle Box 2 was installed in February 1998 at a cost of US $\$ 23,421$. This box was upstream of the first box with a $610 \mathrm{~mm}$ (24 in) CMP at each end of the box. The existing $610 \mathrm{~mm}$ pipe was about $1 \mathrm{~m}$ below grade. This box had inside dimensions of $2.69 \mathrm{~m}(8.83 \mathrm{ft})$ long $\times 1.17 \mathrm{~m}(3.83 \mathrm{ft})$ wide $\times 1.86 \mathrm{~m}$ $(6.12 \mathrm{ft})$ high, with weirs placed at $0.91 \mathrm{~m}(3 \mathrm{ft})$ and $1.96 \mathrm{~m}(6.42 \mathrm{ft})$ from the upstream wall of the box.

Automated samplers were set upstream and downstream of Baffle Box 2 at Sunset Park on December 9, 1999. Baffle Box 2 is located within the road right-of-way of Riverside Drive. In order to reduce aesthetic objections by a homeowner to having boxes in front of his home, the automated sampler enclosures were bolted to wood palettes and mounted on top of inlet grates on Baffle Box 1 that was to the south of the residence. Placement of sampling equipment presented unique challenges for the study due to community perceptions and emphasizes the importance of community involvement. 
Confined space entry requirements were eliminated by mounting the suction strainers and flowmeter probe on $102 \mathrm{~mm}$ (4 in) wide by $460 \mathrm{~mm}$ $(1.5 \mathrm{ft})$ long steel plate welded perpendicular to steel sign posts to form an " $\mathrm{L}$ " shape. The posts were then mounted with concrete anchor bolts to the inside walls such that the steel plates lay on the bottom of the pipes and extended into the pipes upstream and downstream. This method has been used successfully in the past where large debris is not present. A new ISCO model 4250 Doppler Velocity Flowmeter was connected to the inflow side of Baffle Box 2 to record flow. No flowmeter was installed on the downstream side. The single flowmeter initiated sampling of both inlet and outlet autosamplers. One sediment sample was collected from Baffle Box 2 to determine pollutant accumulation in the sediments trapped in the sedimentation chambers. Previous sampling at this site indicated that many pollutant concentrations in the trapped sediments were higher than in the water samples. To further investigate the sediment pollution, more parameters were evaluated for the sediment samples than for the water samples. Sediment samples were collected from each of three chambers and analyzed for nutrients $(\mathrm{N}$ and $\mathrm{P}), \mathrm{BOD}_{5}$, metals, polynuclear aromatic hydrocarbons, and organochlorine pesticides. Discrete sampling for storm flows was used rather than composite sampling in an attempt to better understand the dynamics of the storm events.

Both baffle boxes in this study had three chambers. Due to differences in the type of sediment collected in the three chambers, sediment sampling required two different collection devices. The first and second chambers collected heavier particles consisting mostly of coarse, large-grain sand. Because of the sediment's weight and coarseness, a PVC sampler was required that had adequate vacuum and seal for listing. A PVC sampler with valves was installed near the bottom of the PVC pipe in order to retain the sample. This allowed sampling of the first two chambers. The last chamber generally contained unconsolidated slurry of fine organic and metal-rich sediment with the consistency of pudding. The PVC core sampler was unable to hold such an unconsolidated sample long enough to allow retrieval. A syringe-type muck sampler was used for sampling this chamber.

\subsection{Results}

The cleanout records shown in Table 17.1 for Baffle Box 2 indicated that the box had been cleaned out three times between the installation date and November 30, 1999. A total of 4,806 kg (10,574 lbs) of sediment was removed 
Table 17.1 Baffle box cleanout records.

\begin{tabular}{ccc} 
Maintenance Date & Box No. 1 (lbs) & Box No. 2 (lbs) \\
\hline $1-6-95$ & 3,208 & \\
$1-22-95$ & 1,899 & \\
$7-11-95$ & 1,140 & \\
$8-23-95$ & 1,027 & \\
$9-11-95$ & 1,155 & \\
$10-23-95$ & 1,828 & \\
$12-1-95$ & 2,631 & \\
$7-17-96$ & 688 & \\
$7-18-97$ & 8,316 & \\
$5-11-98$ & 3,766 & \\
$7-12-99$ & 209 & 3,420 \\
$11-30-99$ & 864 & 3,340 \\
$12-11-00$ & 272 & 3,815 \\
Total & 29,548 & 14,389 \\
\hline
\end{tabular}

from this box or $2,558 \mathrm{~kg}(5,639 \mathrm{lbs})$ per year. Due to the irregular frequency of cleanouts and seasonal variability of rainfall events and intensities, it was decided that annual loading rates would be the preferred method of reporting, in order to compare BMPs.

Prior to this installation, $11,083 \mathrm{~kg}(24,433 \mathrm{lbs})$ of sediment were removed from Baffle Box 1, at a rate of $3,851 \mathrm{~kg}(8,490 \mathrm{lbs})$ per year. After installation of Baffle Box 2, only $487 \mathrm{~kg}(1,073 \mathrm{lbs})$ of sediment were collected in Baffle Box 1 over an 18 month period, or $324 \mathrm{~kg}(715 \mathrm{lbs})$ per year. Most settleable solids were trapped in the upstream baffle box, and only a small percentage of larger sediments was collected in the downstream baffle box. When comparing annual removal rates, it appeared that Baffle Box \#2 was not as efficient as Baffle Box 1. It was surmised that the $90^{\circ}$ bend in Baffle Box \#1 resulted in lower linear velocities leading to greater settling than with the straight flow through design of Baffle Box 2.

On December 11,2000 a measurement of sediment accumulation in Baffle Box 2 showed $0.94 \mathrm{~m}^{3}$ (33.09 cu ft) in chamber 1 (the furthest upstream chamber), $0.14 \mathrm{~m}^{3}$ (4.82 cu ft) in chamber 2 , and $0.04 \mathrm{~m}^{3}(1.37 \mathrm{cu} \mathrm{ft})$ in chamber 3 . This is the typical pattern observed in the field and in other laboratory tests, with the first chamber filling fastest. The sediment gradation also followed a pattern of largest particles in chamber 1, and smallest in chamber 3 due to higher settling velocities of the larger particles.

Sediment concentrations found during the 1992 study for Baffle Box 1 are provided in Table 17.2. The sediment concentration results for Baffle Box 2, are presented in Table 17.3. In addition, the composition of the accumulated solids 
Table 17.2 Sediment analysis results for Indialantic Baffle Box 1 (1992).

\begin{tabular}{cccc} 
& \multicolumn{3}{c}{ Metal Parameters $(\mathrm{mg} / \mathrm{kg})$} \\
\hline Metals & $1^{\text {St }}$ Chamber & $2^{\text {nd }}$ Chamber & $3^{\text {rd }}$ Chamber \\
\hline $\mathrm{Al}$ & 32.1 & $\delta$ & $\delta$ \\
$\mathrm{As}$ & 1.13 & 6.70 & 64.80 \\
$\mathrm{Cd}$ & $\mathrm{ND}$ & 0.28 & 0.28 \\
$\mathrm{Cr}$ & 0.04 & 10.05 & 8.22 \\
$\mathrm{Cu}$ & 0.63 & 0.84 & 30.60 \\
$\mathrm{Hg}$ & $\mathrm{ND1}$ & $\delta$ & $\delta$ \\
$\mathrm{Pb}$ & 5.26 & 5.61 & 29.76 \\
$\mathrm{Ni}$ & 2.10 & 16.79 & 130.60 \\
$\mathrm{Zn}$ & 3.23 & 11.04 & 202.40 \\
\hline $\mathrm{m}$ & &
\end{tabular}

$\delta$ - not measured $\quad$ ND - Not detected

was analyzed. Based on the concentrations of each constituent and the mass of sediment removed, the weight of each constituent removed was calculated. The contaminant concentrations (on a mass basis, $\mathrm{mg} / \mathrm{kg}$ ) increased for almost all parameters from chamber 1 to chamber 2, and again from chamber 2 to chamber 3 . With some parameters, the difference between chamber 1 and chamber 3 was several orders of magnitude. This increase in concentration corresponds to decreasing sediment size, with the highest concentrations in the mucky organic material in chamber 3 . Chamber 1 had the largest particle sizes, mostly sand grains, and chamber 2 has a mixture of large and small particle sizes. For $50 \%$ of the parameters, the concentrations are below detectable limits in chamber 1. It is also noted that for most parameters, the highest pollutant mass loads are in chamber 2 , with the next highest in chamber 3 , and the lowest mass in chamber 1 . This is probably due to the fact that there is a much higher percentage of large size particles from airborne beach sands than small sized particles in this area. The unusually high PAH values may have been the result of unauthorized oil being dumped into the pipe system.

Stormwater sediment toxicity has become a controversial topic in Florida, as well as other parts of the country. Florida DEP has determined that sediment from street sweepings may be hazardous and must be disposed in a lined landfill. They have not made a determination of disposal requirements for BMP sediments, but it is probable that similar disposal requirements will be enacted in the foreseeable future.

Evaluation of the 1992 water sample results for Baffle Box 1, taken by grab samples, indicated a $70.6 \%$ TSS removal rate on average (mean). Approximately $50 \%$ of nutrient phosphorus is typically in particulate form. Consequently, an estimated 20 to $35 \%$ removal rate for phosphorus was expected. In 
the 1992 study, total phosphorus sample results showed a $38 \%$ average (median) reduction. Approximately $25 \%$ of the suspended solids were organic in nature. Therefore, BOD and COD were measured. In the 1992 study, a 10 to $17 \%$ reduction in $\mathrm{BOD}_{5}$ was anticipated. However, sample results from 2000 indicated an average $39 \% \mathrm{BOD}_{5}$ reduction for two dates, and one date showed a $25 \%$ increase between inlet and outlet, likely due to resuspension.

The results of monitoring three storm events with autosamplers in 2000 at Baffle Box 2 are shown in Table 17.3. For the 7-17-00 storm there was a sampler malfunction at the inflow sample at time $10 \mathrm{~min}$. Table 17.4 shows average removals for TSS, Total P, BOD, and COD.

\subsection{Discussion}

As is typical in Florida, the rainfall amounts for the three monitored storms were short, low intensity events, ranging from 0.48 inch $(12 \mathrm{~mm})$ in $30 \mathrm{~min}$ to 1.08 inch $(27 \mathrm{~mm})$ in $60 \mathrm{~min}$. A 10-y storm in Florida has a rainfall intensity of about 6 to 7 inches $(150-180 \mathrm{~mm})$ per hour. This led to findings that were applicable for normal Florida weather conditions, but may not be predictive for rainfall events in other regions of the country. These low rainfall events produced low velocities in the inflow pipes, and fairly low pollutant concentrations across the board. Velocities ranged from $0.09-0.45 \mathrm{~m} / \mathrm{s}(0.3-1.5 \mathrm{ft} / \mathrm{s})$ and flow rates ranged from $0.01-0.12 \mathrm{~m}^{3} / \mathrm{s}(0.35-4.33 \mathrm{cfs})$. There was some correlation between removal rates and velocities as seen in Figure 17.1. Because the concentrations and removal rates for Total Phosphorus, BOD and COD were low, and remainder of the discussion will focus on TSS.

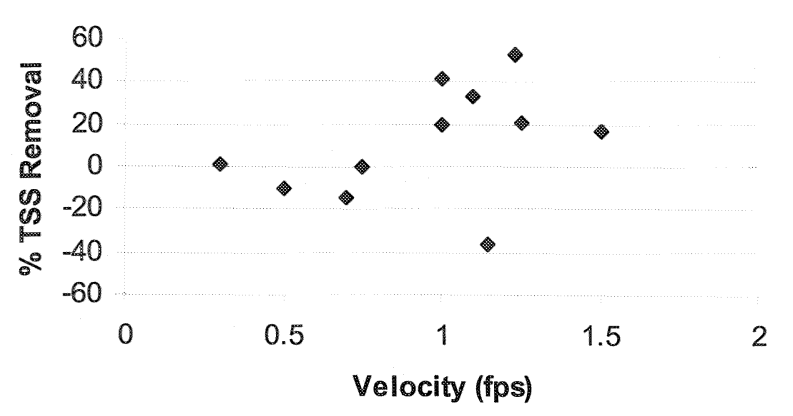

Figure 17.1 TSS removal efficiency vs velocity. 
Table 17.3 Sediment analysis for Indialantic Baffle Box \#2 (2000).

\begin{tabular}{|c|c|c|c|c|c|c|c|c|c|}
\hline \multirow[b]{2}{*}{ Parameter } & \multicolumn{3}{|c|}{ Chamber 1} & \multicolumn{3}{|c|}{ Chamber 2} & \multicolumn{3}{|c|}{ Chamber 3} \\
\hline & $\mathrm{mg} / \mathrm{kg}$ & $\begin{array}{l}\text { kg Sediment } \\
\text { Removed }\end{array}$ & $\begin{array}{c}\text { mg } \\
\text { Removed }\end{array}$ & $\mathrm{mg} / \mathrm{kg}$ & $\begin{array}{l}\text { kg Sediment } \\
\text { Removed }\end{array}$ & $\begin{array}{c}\text { mg } \\
\text { Removed }\end{array}$ & $\mathrm{mg} / \mathrm{kg}$ & $\begin{array}{l}\text { kg Sediment } \\
\text { Removed }\end{array}$ & mg Removed \\
\hline$\%$ solids & $66.60 \%$ & 1,321 & & $48.30 \%$ & 193 & & $19.90 \%$ & 55 & \\
\hline TKN & N/D & & & 600 & & 115,578 & 1,500 & & 82,029 \\
\hline Total $\mathbf{P}$ & 150 & & 198,132 & 2,200 & & 423,786 & 5,100 & & 278,898 \\
\hline Mercury & 0.0067 & & 8.85 & 0.029 & & 5.6 & 0.073 & & 3.99 \\
\hline Aluminum & N/D & & & 800 & & 154,104 & 1,700 & & 92,988 \\
\hline Arsenic & N/D & & & 140 & & 26,988 & 210 & & 11,484 \\
\hline Barium & N/D & & & 140 & & 28,988 & 230 & & 12,577 \\
\hline Chromium & $\mathrm{N} / \mathrm{D}$ & & & 7.8 & & 1,502 & 15 & & 820 \\
\hline Cadmium & 1.9 & & 2,509 & N/D & & & N/D & & \\
\hline Iron & 63 & & 83,215 & 29,000 & & $5,586,270$ & 68,000 & & $3,390,532$ \\
\hline Lead & $\mathrm{N} / \mathrm{D}$ & & & 9.3 & & 1,791 & 25 & & 1,367 \\
\hline Nickel & N/D & & & 2.7 & & 520 & 4.6 & & 251 \\
\hline Zinc & 120 & & 158,505 & 200 & & 38,528 & 910 & & 49,784 \\
\hline Copper & 13 & & 17,171 & 10 & & 1,926 & 35 & & 1,914 \\
\hline \multicolumn{10}{|l|}{ PAH (ug/kg) } \\
\hline Acenaph-thylene & 570 & & 752,901 & 1,500 & & 288,945 & 2,800 & & 153,120 \\
\hline Benzo (A) Pyrene & N/D & & & 120 & & 23,115 & N/D & & \\
\hline Benzo(ghi) Perylene & N/D & & & N/D & & & 290 & & 15,858 \\
\hline Fluoran-thene & N/D & & & 160 & & 30,820 & 290 & & 18,585 \\
\hline Fluorene & 200 & & 264,176 & 560 & & 107,872 & 2,500 & & 1,36715 \\
\hline 1-Methylnaph-thalen & 1,200 & & $1,585,056$ & 11,000 & & $2,118,930$ & 14,000 & & 765,804 \\
\hline Naphtha-lene & 150 & & 1,981 & 170 & & 32,747 & 380 & & 20,780 \\
\hline Pyrene & N/D & & & 140 & & 26,968 & $\mathrm{~N} / \mathrm{D}$ & & \\
\hline \multicolumn{10}{|l|}{ Pesticides } \\
\hline Dieldrin & $\mathrm{N} / \mathrm{D}$ & & & 12 & & 2,311 & $\mathrm{~N} / \mathrm{D}$ & & \\
\hline
\end{tabular}


Table 17.3 cont'd. Indialantic Baffle Box Storm 7-17-00 Rainfall - (0.48”) in 30 minutes

\begin{tabular}{|c|c|c|c|c|c|c|}
\hline At Time 0 & Flow Rate cfs & Pipe Velocity fps & $\begin{array}{r}\mathrm{TSS} \\
\mathrm{mg} / \mathrm{L}\end{array}$ & $\begin{array}{c}\text { Total Phosphorus } \\
\mathrm{mg} / \mathrm{L}\end{array}$ & $\begin{array}{l}\mathrm{BOD} \\
\mathrm{mg} / \mathrm{L}\end{array}$ & $\begin{array}{l}\mathrm{COD} \\
\mathrm{mg} / \mathrm{L}\end{array}$ \\
\hline $\begin{array}{l}\text { Inflow } \\
\text { Outflow } \\
\text { Change } \\
\% \text { Change }\end{array}$ & 0.37 & 0.70 & $\begin{array}{c}14 \\
16 \\
+2 \\
+14.3 \\
\end{array}$ & $\begin{array}{l}0.54 \\
0.39 \\
-0.15 \\
-27.8 \\
\end{array}$ & $\begin{array}{c}3 \\
2 \\
-1 \\
-33.3 \\
\end{array}$ & $\begin{array}{c}47 \\
29 \\
-18 \\
-38.3 \\
\end{array}$ \\
\hline At 10 Minutes & Flow Rate cfs & Pipe Velocity fps & $\begin{array}{l}\mathrm{TSS} \\
\mathrm{mg} / 1\end{array}$ & $\begin{array}{c}\text { Total Phosphorus } \\
\mathrm{mg} / 1\end{array}$ & $\begin{array}{l}\mathrm{BOD} \\
\mathrm{mg} / 1\end{array}$ & $\begin{array}{l}\mathrm{COD} \\
\mathrm{mg} / \mathrm{l}\end{array}$ \\
\hline $\begin{array}{l}\text { Inflow } \\
\text { Outflow } \\
\text { Change } \\
\% \text { Change }\end{array}$ & 0.84 & 0.70 & $\begin{array}{l}-- \\
7 \\
-- \\
-\end{array}$ & $\begin{array}{c}0.32 \\
0.39 \\
+0.07 \\
+21.9 \\
\end{array}$ & $\begin{array}{l}- \\
2 \\
-- \\
-\end{array}$ & $\begin{array}{c}19 \\
23 \\
+4 \\
+21.1 \\
\end{array}$ \\
\hline At 20 Minutes & Flow Rate cfs & Pipe Velocity fps & $\begin{array}{l}\mathrm{TSS} \\
\mathrm{mg} / 1\end{array}$ & $\begin{array}{c}\text { Total Phosphorus } \\
\mathrm{mg} / 1 \\
\end{array}$ & $\begin{array}{l}\mathrm{BOD} \\
\mathrm{mg} / 1\end{array}$ & $\begin{array}{l}\mathrm{COD} \\
\mathrm{mg} / 1\end{array}$ \\
\hline $\begin{array}{l}\text { Inflow } \\
\text { Outflow } \\
\text { Change } \\
\% \text { Change } \\
\end{array}$ & 1.04 & 0.50 & $\begin{array}{r}50 \\
56 \\
+6 \\
+10.7 \\
\end{array}$ & $\begin{array}{r}1.7 \\
2.2 \\
+0.5 \\
+29.4 \\
\end{array}$ & $\begin{array}{l}5 \\
5 \\
0 \\
0 \\
\end{array}$ & $\begin{array}{c}45 \\
45 \\
0 \\
0 \\
\end{array}$ \\
\hline At 30 Minutes & Flow Rate cfs & $\begin{array}{l}\text { Pipe Velocity } \\
\text { fps }\end{array}$ & $\begin{array}{l}\mathrm{TSS} \\
\mathrm{mg} / 1\end{array}$ & $\begin{array}{c}\text { Total Phosphorus } \\
\mathrm{mg} / 1 \\
\end{array}$ & $\begin{array}{l}\mathrm{BOD} \\
\mathrm{mg} / 1\end{array}$ & $\begin{array}{l}\mathrm{COD} \\
\mathrm{Mg} / 1\end{array}$ \\
\hline $\begin{array}{l}\text { Inflow } \\
\text { Outflow } \\
\text { Change } \\
\% \text { Change }\end{array}$ & 0.85 & 0.30 & $\begin{array}{c}28 \\
22 \\
-6 \\
-27.3 \\
\end{array}$ & $\begin{array}{c}1.2 \\
1.2 \\
0 \\
0 \\
\end{array}$ & $\begin{array}{c}3 \\
2 \\
-1 \\
-33.3 \\
\end{array}$ & $\begin{array}{c}26 \\
24 \\
-2 \\
-7.7 \\
\end{array}$ \\
\hline Storm Average Reduction & & & $0.58 \%$ & $-5.88 \%$ & $16.65 \%$ & $6.23 \%$ \\
\hline
\end{tabular}


Table 17.3 cont'd. Indialantic Baffle Box Storm 7-21-00 Rainfall - (0.54") in 45 minutes.

\begin{tabular}{|c|c|c|c|c|c|c|}
\hline At Time 0 & Flow Rate cfs & Pipe Velocity fps & $\begin{array}{l}\text { TSS } \\
\mathrm{mg} / \mathrm{L}\end{array}$ & $\begin{array}{c}\text { Total Phosphorus } \\
\mathrm{mg} / \mathrm{L}\end{array}$ & $\begin{array}{l}\mathrm{BOD} \\
\mathrm{mg} / \mathrm{L}\end{array}$ & $\begin{array}{l}\mathrm{COD} \\
\mathrm{mg} / \mathrm{L}\end{array}$ \\
\hline $\begin{array}{l}\text { Inflow } \\
\text { Outflow } \\
\text { Change } \\
\% \text { Change }\end{array}$ & 0.35 & 1.23 & $\begin{array}{c}50 \\
24 \\
-26 \\
-52.4 \\
\end{array}$ & $\begin{array}{l}0.59 \\
0.18 \\
-0.41 \\
-69.5 \\
\end{array}$ & $\begin{array}{c}12 \\
7 \\
-5 \\
-41.7 \\
\end{array}$ & $\begin{array}{c}85 \\
61 \\
-24 \\
-28.2 \\
\end{array}$ \\
\hline At 10 Minutes & Flow Rate cfs & Pipe Velocity fps & $\begin{array}{l}\mathrm{TSS} \\
\mathrm{mg} / \mathrm{l}\end{array}$ & $\begin{array}{c}\text { Total Phosphorus } \\
\mathrm{mg} / \mathrm{l}\end{array}$ & $\begin{array}{l}\mathrm{BOD} \\
\mathrm{mg} / \mathrm{l}\end{array}$ & $\begin{array}{l}\mathrm{COD} \\
\mathrm{mg} / \mathrm{l}\end{array}$ \\
\hline $\begin{array}{l}\text { Inflow } \\
\text { Outflow } \\
\text { Change } \\
\% \text { Change }\end{array}$ & 0.37 & 1.15 & $\begin{array}{c}9 \\
14 \\
+5 \\
+35.7 \\
\end{array}$ & $\begin{array}{l}0.24 \\
0.17 \\
-.07 \\
-29.2 \\
\end{array}$ & $\begin{array}{c}4 \\
5 \\
+1 \\
+25 \\
\end{array}$ & $\begin{array}{c}48 \\
50 \\
+2 \\
+4.2 \\
\end{array}$ \\
\hline At 20 Minutes & Flow Rate cfs & Pipe Velocity fps & $\begin{array}{l}\text { TSS } \\
\mathrm{mg} / 1\end{array}$ & $\begin{array}{c}\text { Total Phosphorus } \\
\mathrm{mg} / 1\end{array}$ & $\begin{array}{l}\mathrm{BOD} \\
\mathrm{mg} / \mathrm{l}\end{array}$ & $\begin{array}{l}\mathrm{COD} \\
\mathrm{mg} / \mathrm{l}\end{array}$ \\
\hline $\begin{array}{l}\text { Inflow } \\
\text { Outflow } \\
\text { Change } \\
\% \text { Change }\end{array}$ & 0.70 & 1.00 & $\begin{array}{c}75 \\
44 \\
-31 \\
-41.3\end{array}$ & $\begin{array}{c}1.3 \\
0.57 \\
-.73 \\
-56.2\end{array}$ & $\begin{array}{c}8 \\
6 \\
-2 \\
-25\end{array}$ & $\begin{array}{c}78 \\
55 \\
-23 \\
-29.5 \\
\end{array}$ \\
\hline At 30 Minutes & Flow Rate cfs & Pipe Velocity fps & $\begin{array}{l}\text { TSS } \\
\mathrm{mg} / 1\end{array}$ & $\begin{array}{c}\text { Total Phosphorus } \\
\mathrm{mg} / 1\end{array}$ & $\begin{array}{l}\mathrm{BOD} \\
\mathrm{mg} / \mathrm{l}\end{array}$ & $\begin{array}{l}\mathrm{COD} \\
\mathrm{mg} / 1\end{array}$ \\
\hline $\begin{array}{c}\text { Inflow } \\
\text { Outflow } \\
\text { Change } \\
\% \text { Change }\end{array}$ & 1.33 & 0.75 & $\begin{array}{c}30 \\
30 \\
0 \\
0 \\
\end{array}$ & $\begin{array}{l}0.78 \\
0.64 \\
-0.14 \\
-17.9 \\
\end{array}$ & $\begin{array}{l}6 \\
6 \\
0 \\
0 \\
\end{array}$ & $\begin{array}{r}45 \\
50 \\
+5 \\
+11.1 \\
\end{array}$ \\
\hline $\begin{array}{c}\text { Storm Average } \\
\text { Reduction }\end{array}$ & & & $14.50 \%$ & $43.20 \%$ & $10.42 \%$ & $10.60 \%$ \\
\hline
\end{tabular}


Table 17.3 cont'd. Indialantic Baffle Box Storm 9-6-00 Rainfall - (1.08") in 60 minutes.

\begin{tabular}{|c|c|c|c|c|c|c|}
\hline At Time 0 & Flow Rate cfs & Pipe Velocity cfs & $\begin{array}{l}\mathrm{TSS} \\
\mathrm{mg} / \mathrm{L}\end{array}$ & $\begin{array}{c}\text { Total Phosphorus } \\
\mathrm{mg} / \mathrm{L}\end{array}$ & $\begin{array}{l}\mathrm{BOD} \\
\mathrm{mg} / \mathrm{L}\end{array}$ & $\begin{array}{l}\mathrm{COD} \\
\mathrm{mg} / \mathrm{L}\end{array}$ \\
\hline Inflow & 0.37 & 1.0 & 5 & 0.77 & 4 & 32 \\
\hline Outflow & & & 4 & 0.71 & 4 & 34 \\
\hline Change & & & -1 & -.06 & 0 & +2 \\
\hline$\%$ Change & & & -20 & -7.8 & 0 & +6.2 \\
\hline \multirow[t]{2}{*}{ At 10 Minutes } & Flow Rate cfs & Pipe Velocity cfs & TSS & Total Phosphorus & BOD & COD \\
\hline & & & $\mathrm{mg} / 1$ & $\mathrm{mg} / \mathrm{l}$ & $\mathrm{mg} / \mathrm{l}$ & $\mathrm{mg} / 1$ \\
\hline Inflow & 3.37 & 1.25 & 44 & 1.6 & 5 & 36 \\
\hline Outflow & & & 35 & 1.5 & 4 & 35 \\
\hline Change & & & -9 & -.1 & -1 & -1 \\
\hline$\%$ Change & & & -20.5 & -6.2 & -20 & -2.8 \\
\hline \multirow[t]{2}{*}{ At 20 Minutes } & Flow Rate cfs & Pipe Velocity cfs & TSS & Total Phosphorus & $\mathrm{BOD}$ & COD \\
\hline & & & $\mathrm{mg} / 1$ & $\mathrm{mg} / 1$ & $\mathrm{mg} / 1$ & $\mathrm{mg} / 1$ \\
\hline Inflow & 4.33 & 1.50 & 30 & 1.5 & 3 & 30 \\
\hline Outflow & & & 25 & 1.3 & 3 & 30 \\
\hline Change & & & -5 & -0.2 & 0 & 0 \\
\hline$\%$ Change & & & -16.7 & -13.3 & 0 & 0 \\
\hline \multirow[t]{2}{*}{ At 30 Minutes } & Flow Rate cfs & Pipe Velocity cfs & TSS & Total Phosphorus & $\mathrm{BOD}$ & COD \\
\hline & & & $\mathrm{mg} / 1$ & $\mathrm{mg} / \mathrm{l}$ & $\mathrm{mg} / \mathrm{l}$ & $\mathrm{Mg} / 1$ \\
\hline Inflow & 2.96 & 1.10 & 3 & 0.80 & 2 & 24 \\
\hline Outflow & & & 2 & 0.73 & 2 & 26 \\
\hline Change & & & -1 & -.07 & 0 & +2 \\
\hline$\%$ Change & & & -33.3 & -8.8 & 0 & +8.3 \\
\hline Storm Average Reduction & & & $22.62 \%$ & $9.02 \%$ & $5.00 \%$ & $2.92 \%$ \\
\hline
\end{tabular}


Table 17.4 Average removals for all 3 storms.

\begin{tabular}{ccccc}
\hline Parameter & TSS & Total Phosphorus & BOD & COD \\
\hline$\%$ Removal & 12.6 & 15.5 & 10.7 & 6.6 \\
\hline
\end{tabular}

Discrete sampling demonstrated variable inflow concentrations, although only one storm exhibited a typical first flush effect. TSS removals ranged from $0.58 \%$ to $22.62 \%$, with an average of $13 \%$. These removal efficiencies were unexpectedly low in light of the large masses of sediment removed. Upon further analysis, it was noted that the high masses in chambers 1 and 2 consist of large sand particles that made up the bedload in the pipe. This bedload material was not detected as TSS by the autosamplers, but nevertheless was being flushed into the baffle box. Stahre and Urbonas (1990) concluded that a relatively small number of large size particles can represent a relatively significant load by volume and weight of the total TSS measured in stormwater.

A study by Pandit (1996) showed similar results with $86-90 \%$ removal rates for large grain sand and $20-30 \%$ removal for ultra fine sediment. Observations through clear pipes in a lab showed that upon initiation of flow, the fine sediment particles were rapidly flushed from the bedload, and the coarse particles required extended flow times to be completely flushed from the pipe. This phenomenon has been well documented in sanitary sewer studies by Berlamont, et al. (2000) and Nalluri and Ota (2000) and many others. It was attributed to variable shear stresses in partially filled pipes, particle sizes and shapes, pipe shape, settling velocities, and other unexplained variables. Therefore, the autosamplers were measuring only fine sediment particles capable of being suspended at very low velocities. At this location most sediment particles were large coarse sands from infiltration pipes and beach wind deposits.

In a study of sedimentation basins, Kuo (1976) concluded that the removal efficiency was independent of basin depth. He did find that removal efficiency increased with basin length. The baffle box length was arbitrarily chosen. Kuo's results indicate that using a baffle box as long as feasible will increase efficiency. Usually the precast box weight governs the box size. Large boxes require large cranes for lifting or necessitate laborious cast in place installation. Kuo also found that removal efficiencies varied from $12 \%-90 \%$ for a length/depth ratio of 5, depending upon particle size and flow rates.

Another conclusion from Pandit (1996) was that the removal efficiency of a baffle box decreased with decreasing concentration. The TSS concentrations he used in laboratory analysis ranged from 50-1000 mg/l. Stahre and Urbonas (1990) also concluded that TSS removal efficiencies in sedimentation 
tunnels were very poor when initial concentrations are around $10 \mathrm{mg} / \mathrm{l}$. Concentration vs. concentration change for the discrete sampling events was plotted in Figure 17.2. It is apparent that as TSS concentration was reduced, the baffle box became less efficient, to the point of exporting sediment at concentrations below $20 \mathrm{mg} / \mathrm{l}$.

Figure 17.2 TSS concentration vs. TSS removal.

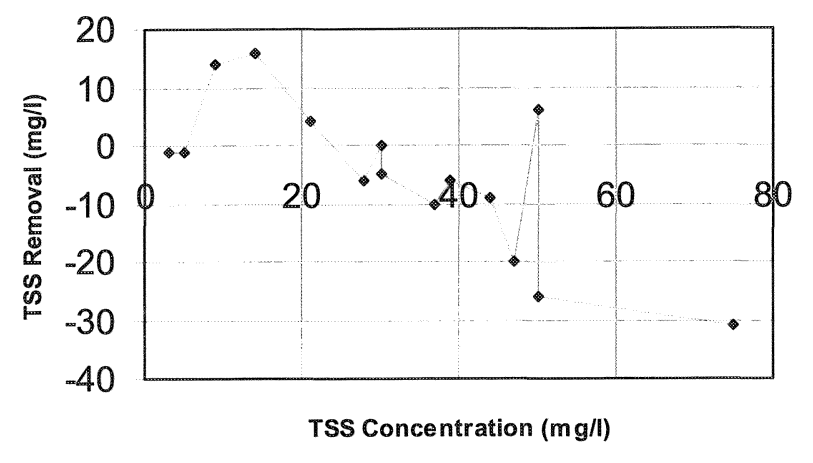

\subsection{Conclusions}

At the study location, where sediment is predominantly large sand that settles rapidly, the use of two baffle boxes in series demonstrated predictable results: the first box trapping much larger quantities of sediment than the second box. This indicated that the first box trapped most heavy sediment that was capable of being caught with a BMP depending upon simple settling action. If there is a need to clean stormwater runoff to a higher level than provided with a single baffle box, adding a second baffle box can provide further sediment removal. The cost-effectiveness of a second baffle box in series should be carefully considered.

Testing in 1992 showed a TSS removal rate of $70.9 \%$, while tests in 2000 showed an average of $12.6 \%$ TSS removal. The 1992 tests were grab samples and velocities and flow rates were not recorded. With the low velocity and flows in the 2000 storm events, low removal rates were observed. It is hypothesized that the 1992 storms produced higher flow rates, which, based upon laboratory testing, would have had higher TSS removal efficiency than the 2000 events. 
It is also hypothesized that the original box with a right angle entrance would have greater momentum changes, giving more opportunity for sedimentation than simple gravity action in the second box.

Heavy metal, $\mathrm{PAH}$, and volatile solids concentrations were significantly higher in the fine, organic sediments than in heavy sand sediments. Sartor and Boyd (1977) also observed this relationship. The relationship between increased concentration of these pollutants and particle size was not studied in this test, but would be a prime subject for future examination.

Over $15,876 \mathrm{~kg}(35,000 \mathrm{lbs})$ of sediment was removed from the two baffle boxes during an 8-y period. Baffle boxes have been demonstrated to be effective BMPs for the removal of coarse sediments, trash, and debris. Due to low rainfall events and low pipe velocities encountered during the monitoring period, it was concluded that complete effectiveness of baffle boxes as BMPs was not determined. The removal efficiencies at velocities below $0.46 \mathrm{~m} / \mathrm{s}(1.5 \mathrm{ft} / \mathrm{s})$ and concentrations noted were estimated at $13 \%$ for TSS, $19 \%$ for total phosphorus, $11 \%$ for BOD, and $7 \%$ for COD. The removal efficiency for TSS is similar to previous testing by Pandit (1996) in laboratory conditions for fine sediment. Therefore, the TSS removal rates of $89 \%$ for large grain sediment that Pandit measured is also presumed to be valid. In addition, TSS removal was more effective at higher concentrations than at lower concentrations. This conclusion was supported by Stahre and Urbonas (1990) who found that TSS sedimentation increased significantly as particle volume in the water column increased. A greater concentration of particles probably increases colloidal activity, which in turn leads to decreased settling times.

The measured TSS removal rates were representative of fine organic sediments at very low concentrations and low velocities, but not for the larger sand sediments collected in the baffle boxes. Removal efficiencies for sediment traps will vary with velocity, particle size, and concentration. Therefore an estimate of TSS removal efficiencies for any type of sediment traps should include these variables.

The inability of an autosampler to monitor bedloads prevents its use to determine the true sediment removal effectiveness of baffle boxes, or any other type of sediment trapping BMPs that remove bedload materials. Additional testing with different monitoring equipment, preferably in controlled laboratory conditions, should be done to measure sediment removals for BMPs. The use of autosamplers to measure pollutants other than heavy sediment still gives valid results for those constituents. 


\section{Bibliography}

Berlamont, Jean, Koen Trouw, and Gert Luyckx, (2000). "Shear Stress Distribution in Partially Filled Pipes and Its Effect on the Modeling of Sediment Transport in Storm Drains". ASCE 2000 Joint Conference on Water Resources Engineering. Nalluri, Chandra and Jose J. Ota, (2000). "Non-Cohesive Sediment Transport in Clean Sewers and with Small Mobile Beds". ASCE 2000 Joint Conference on Water Resources Engineering

Pandit, Dr. Ashok and Ganesh Gopatakrishnan, (1996). "Physical Modeling of a Stormwater Sediment Removal Box". Masters Thesis. www.stormwaterresources.com - Library paper no. 041

Sarter, J.D. and Boyd, G.B., "Water Pollutant Aspects of Street Surface Contaminants" (1977). U.S. EPA, EPA-600/2-77-047,1977.

Stahre, Peter and Ben Urbonas, (1990). "Stormwater Detention for Drainage, Water Quality, and CSO Management". 
